\title{
The backbone stereochemistry influences the intracellular distribution and uptake mechanism of oligoarginines
}

\author{
Yan $\mathrm{Ma}^{*, \dagger}$, Cheng Gong*,†, Yilong $\mathrm{Ma}^{*, \dagger}$ \\ and Yu-Hui Zhang*, $\uparrow, \S$ \\ *Britton Chance Center for Biomedical Photonics \\ Wuhan National Laboratory for Optoelectronics-Huazhong \\ University of Science and Technology (HUST) \\ Wuhan 430074, P. R. China \\ ${ }^{\dagger}$ MoE Key Laboratory for Biomedical Photonics \\ Department of Biomedical Engineering \\ Huazhong University of Science and Technology \\ Wuhan 430074, P. R. China \\ *Wuhan Blood Center, 430030 \\ Wuhan, P. R. China \\ §hangyh@mail.hust.edu.cn
}

Received 9 September 2013

Accepted 27 November 2013

Published 9 January 2014

\begin{abstract}
D-arginine oligomers have been widely used as intracellular delivery vectors both in in vitro and in vivo application. Nevertheless, their internalization pathway is obscure and conflicting results have been obtained concerning their intracellular distribution. In this study, we demonstrate that octa-D-arginine $\left(\mathrm{r}_{8}\right)$ undergoes diffuse localization throughout the cytoplasm and nucleus even at low concentrations and that $\mathrm{r}_{8}$ ( $\mathrm{r}$ : D-arginine) enters the cells via direct membrane translocation, unlike $\mathrm{R}_{8}$ (R: L-arginine), of which endocytosis is the major internalization pathway. The observation that $R_{8}$ and $r_{8}$ enter the cells through two clearly distinct internalization pathways suggests that the backbone stereochemistry affects the uptake mechanism of oligoarginines.
\end{abstract}

Keywords: Cell-penetrating peptide; oligoarginine; heterogeneous; mechanism; intracellular distribution.

This is an Open Access article published by World Scientific Publishing Company. It is distributed under the terms of the Creative Commons Attribution 3.0 (CC-BY) License. Further distribution of this work is permitted, provided the original work is properly cited. 


\section{Introduction}

A number of therapeutic molecules available for intracellular targets is severely limited by the general requirement that they must breach cell membranes. Cell-penetrating peptides (CPPs) can deliver a range of membrane-impermeable molecules (e.g., synthetic small drugs, DNA, peptides, proteins and siRNA) into living cells or tissues, making them potential vehicles for various therapeutics. ${ }^{1-3}$ Among the existing CPPs, homogeneous oligoarginine peptides (L or D) are of particular interest, ${ }^{4,5}$ they are the most widely studied and frequently employed CPPs in both in vitro and in vivo applications because they are accessibly synthesized and oligomers as short as $7 \sim 12$ amino acid residues are of high cellular uptake efficiency. ${ }^{6-15}$

For L-arginine oligomers, many studies have been carried out to investigate their cellular uptake efficiency, intracellular distribution and uptake mechanisms. ${ }^{6}$ Endocytosis, including macropinocytosis has been pointed out to be the major internalization pathway of L-arginine oligomers at low concentrations. ${ }^{16-19}$ Thus, the internalized L-arginine oligomers (either alone or linked to cargos) are trapped in punctate perinuclear vesicles, making it difficult for them to access the cytosol or nucleus to exert their cellular functions. Moreover, L-arginine oligomers are instable toward proteases, which severely diminishes their bioavailability. ${ }^{4}$

Compared with their L-counterparts, D-arginine oligomers have been reported to possess a higher transduction and greater protease resistance ${ }^{4,20}$ and are used more often in in vivo applications. ${ }^{10}$ But in contrast, there are much fewer studies on of D-arginine oligomers. Moreover, to this point, most of the studies are focused on the cellular uptake efficiency of Darginine oligomers. ${ }^{4,20}$ However, the high cellular uptake efficiency of CPPs does not always relate to high functional effectiveness of their cargos once inside the cell. ${ }^{21,22}$ The intracellular distribution and internalization pathway employed influence the destination and biological efficacy of intracellularly delivered therapeutic agents. By now, the intracellular distributions of D-arginine oligomers are still confusing. Some groups observed that fluorescently labeled $R_{8}$ and octa-D-arginine $\left(\mathrm{r}_{8}\right)$, are co-localized extensively in HeLa cells with predominantly vesicular staining at $10 \mu \mathrm{M}$, suggesting that D-arginine oligomers enter cells through endocytosis, too. ${ }^{18,23}$ However, conflicting results were obtained by Martin et al. ${ }^{24}$ They reported that the decapeptide $\mathrm{r}_{10}$ (r: D-arginine) is uniformly localized throughout the cytoplasm and nucleoli with few punctate signals even at $2.5 \mu \mathrm{M}$. As far as known, there are few publications on the uptake mechanism of D-arginine oligomers.

Herein, we first investigated the intracellular distribution and uptake mechanism of octa-D-arginine $\left(\mathrm{r}_{8}\right)$. We believed that advanced imaging technology and optimized methods would renew our understanding of CPPs. ${ }^{25-28}$ We demonstrate that $r_{8}$ enters the cells by direct membrane translocation rather than endocytosis and becomes diffusely localized throughout the cytosol and nucleoli, rather than remaining trapped in endosomal vesicles. Our results suggest that the backbone stereochemistry affects the cellular uptake mechanism of oligoarginine peptides.

\section{Materials and Methods}

\subsection{Synthesis of peptides}

All the peptides were synthesized and coupled to a fluorescent label (FITC, fluorescein isothiocyanate), through an aminohexanoic acid (Ahx) spacer at the N-terminus, by GL Biochem (Shanghai, P. R. China). The peptides were purified through preparative HPLC to a purity of greater than $95 \%$ and their appropriate masses were confirmed using electrospray ionization (ESI) mass spectrometry.

The peptides were each dissolved in phosphatebuffered saline (PBS, pH 7.4) and then their concentrations were determined in terms of the absorption of fluorescein at $498 \mathrm{~nm}(\varepsilon: 64,900)$ using a Lambda 950 UV spectrometer (Perkin-Elmer). The accuracy of this method for determining peptide concentrations was established by weighing selected samples and dissolving them in a known amount of PBS.

\subsection{Cells and cell cultures}

HeLa cells were cultured in Dulbecco's modified Eagles's medium (DMEM) supplemented with $10 \%$ fetal bovine serum (FBS). Cells were grown in a $\mathrm{CO}_{2}(5 \%, \mathrm{v} / \mathrm{v})$ atmosphere at $37^{\circ} \mathrm{C}$ to subculture.

\subsection{Confocal microscopy}

HeLa cells were seeded into eight-well Lab-Tek chamber slides at a density of $1.0 \times 10^{4}$ cells/well in DMEM $(200 \mu \mathrm{L})$ containing $10 \%$ FBS. The cells 
were then grown under a $\mathrm{CO}_{2}(5 \%, \mathrm{v} / \mathrm{v})$ atmosphere at $37^{\circ} \mathrm{C}$ overnight.

The FITC-labeled peptides were dissolved with serum-free DMEM. HeLa cells were washed one time with PBS and then the above FITC-labeled peptide solution $(300 \mu \mathrm{L})$ was gently added to the cells. After incubation for $5 \mathrm{~min}$ at $37^{\circ} \mathrm{C}$, the supernatant medium were discarded and a solution $(200 \mu \mathrm{L})$ of trypan blue $(500 \mu \mathrm{g} / \mathrm{mL})$ in PBS was added to quench the extracellular fluorescence from the outer membranebound peptides for $1 \mathrm{~min}$. The cells were then washed three times with PBS containing propidium iodide $(\mathrm{PI}, 8 \mu \mathrm{g} / \mathrm{mL})$. The cells were analyzed live in serumfree DMEM $(250 \mu \mathrm{L})$ using an FV1000 confocal laser scanning microscope (Olympus, Japan) equipped with a $60 \mathrm{X}$ oil-immersion objective lens (NA 1.4).

To record the time lapse of the transduction, CPPs $(5 \mu \mathrm{M})$ and Hoechst $33342(3 \mu \mathrm{g} / \mathrm{mL})$ were diluted with serum-free DMEM $(300 \mu \mathrm{L})$ and allowed to stand for $10 \mathrm{~min}$ at $37^{\circ} \mathrm{C}$. The cells were washed three times with PBS and then the above FITC-labeled peptide/Hoechst 33342 mixture was gently added to the cells. The cells were analyzed using an FV1000 confocal laser scanning microscope (Olympus, Japan) equipped with a $60 \mathrm{X}$ oil-immersion objective lens (NA 1.4) immediately. The images were obtained every $15 \mathrm{~s}$.

For $4{ }^{\circ} \mathrm{C}$ experiments, the cells were preincubated at $4^{\circ} \mathrm{C}$ for $30 \mathrm{~min}$, washed with ice-cold PBS and incubated with the peptides $(5 \mu \mathrm{M})$ in ice-cold serum-free DMEM $(300 \mu \mathrm{L})$ for 5 min at $4^{\circ} \mathrm{C}$. After incubation, the cells were washed with trypan blue $(500 \mu \mathrm{g} / \mathrm{mL}$ in PBS) and PBS buffer containing PI $(8 \mu \mathrm{g} / \mathrm{mL})$, and then analyzed in serum-free DMEM immediately.

For experiments investigating the role of membrane potential, a buffer $\operatorname{PBS}\left(\mathrm{K}^{+}\right)$, where the sodium salt in PBS was replaced with equimolar amounts of the equivalent potassium salt, was used. HeLa cells were washed with PBS or PBS $\left(\mathrm{K}^{+}\right)$and incubated with the peptides $(2.5 \mu \mathrm{M})$ in $\mathrm{PBS}$ or $\operatorname{PBS}\left(\mathrm{K}^{+}\right)(300 \mu \mathrm{L})$, respectively. After incubation at $37^{\circ} \mathrm{C}$ for $5 \mathrm{~min}$, the cells were washed with trypan blue $(500 \mu \mathrm{g} / \mathrm{mL}$ in PBS) and PBS buffer containing PI $(8 \mu \mathrm{g} / \mathrm{mL})$, and then analyzed in DMEM containing FBS immediately.

For the detection of FITC-labeled peptides, the fluorescence signals were detected using a 500$555 \mathrm{~nm}$ emission filter, with excitation using a $488 \mathrm{~nm}$ Ar laser. For the detection of PI, the fluorescence signals were detected using a $600-670 \mathrm{~nm}$ emission filter, with excitation using a $488 \mathrm{~nm}$ Ar laser. For the detection of Hoechst 33342, the excitation laser line was $405 \mathrm{~nm}$ and the emission filter was $462-523 \mathrm{~nm}$.

\subsection{Flow cytometry (FACS)}

HeLa cells $\left(5 \times 10^{4}\right.$ cells/well $)$ were seeded into a 24 well plate. After complete adhesion, the cells in logarithmic phase were incubated with FITC-labeled peptides at various concentrations in the respective buffers $(300 \mu \mathrm{L})$ for $5 \mathrm{~min}$ at $37^{\circ} \mathrm{C}$ or $4^{\circ} \mathrm{C}$. For $4{ }^{\circ} \mathrm{C}$ experiments, cells were preincubated at $4^{\circ} \mathrm{C}$ for $30 \mathrm{~min}$. After washing one time with trypan blue $(1 \mathrm{mg} / \mathrm{mL}$ in PBS $)$ and three times with PBS, the cells were detached through trypsinization for $3 \mathrm{~min}$. After the trypsin was removed, a solution $(300 \mu \mathrm{L})$ of DMEM containing 10\% FBS was added. The resuspended cells were centrifuged at $4000 \mathrm{rpm}$ for $5 \mathrm{~min}$. The cells were washed with a solution $(250 \mu \mathrm{L})$ of icecold PBS containing PI $(5 \mu \mathrm{g} / \mathrm{mL})$ to assess viability. Finally, the cells were resuspended in PBS containing $1 \%$ FBS and placed on ice and in the dark until required for analysis. Each experiment was performed three times. In each case, the fluorescence of atleast 10,000 vital cells was acquired. Cells were analyzed using an Epics XL (Beckman Coulter); data analysis was performed using WinMdi software.

\subsection{Incubation with inhibitors of endocytosis}

Cells were treated with the indicated inhibitors $[10 \mathrm{mg} / \mathrm{mL}$ Chlorpromazine (CPZ), $5 \mathrm{mM} \mathrm{M} \beta \mathrm{CD}$ or $50 \mathrm{mM}$ 5-(N-ethyl-N-isopropyl)amiloride (EIPA)] for $30 \mathrm{~min}$ at $37^{\circ} \mathrm{C}$ in DMEM containing $10 \%$ FBS. Then, the medium was discarded and serum-free DMEM containing FITC- $\mathrm{r}_{8}(5 \mu \mathrm{M})$ as well as the corresponding inhibitor was added. After $30 \mathrm{~min}$ of incubation at $37^{\circ} \mathrm{C}$, the cells were washed with trypan blue $(500 \mu \mathrm{g} / \mathrm{mL}$ in PBS $)$ and PBS buffer containing PI $(8 \mu \mathrm{g} / \mathrm{mL})$, and then analyzed in $10 \%$ serum-DMEM immediately by fluorescence microscopy or flow cytometry.

\section{Results}

\subsection{The intracellular distribution of octa-D-arginine $\left(\mathrm{r}_{8}\right)$}

We synthesized octa-D-arginine $\left(\mathrm{r}_{8}\right)$ using standard solid phase chemistry and coupled it to FITC, a 

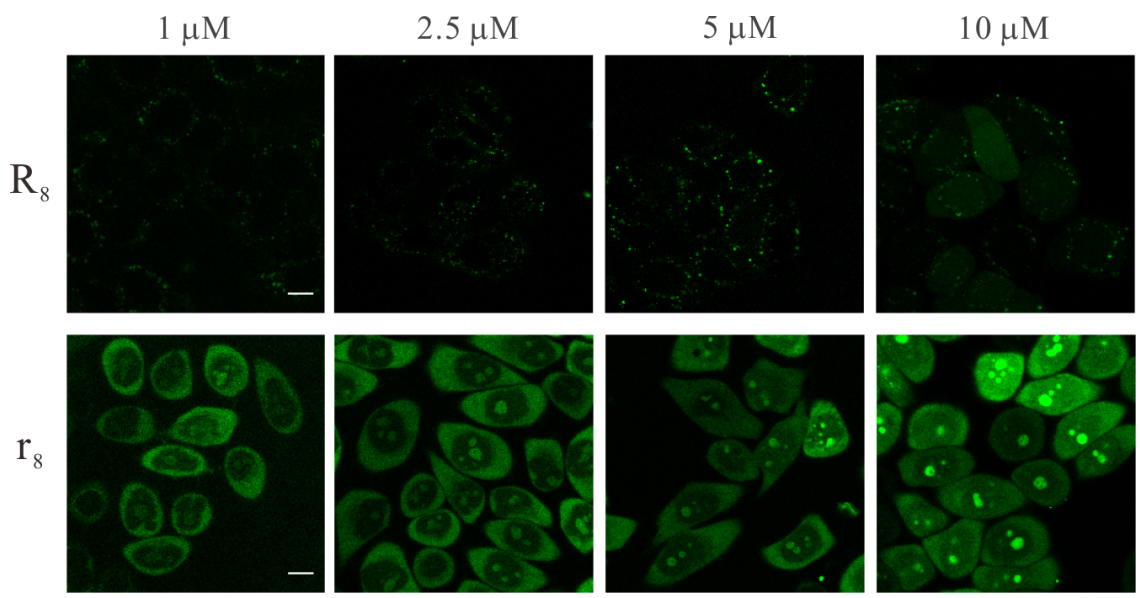

Fig. 1. Confocal microscopy images of living HeLa cells after incubation with the FITC-labeled peptides (various concentrations) at $37^{\circ} \mathrm{C}$ for $5 \mathrm{~min}$ in serum-free DMEM $(300 \mu \mathrm{L})$. Scale bar: $10 \mu \mathrm{m}$.

widely used fluorescent label and cell-impermeable cargo model, ${ }^{17,18}$ through an aminohexanoic acid (Ahx) spacer, at the N-terminus. For comparison, we also synthesized octa-L-arginine $\left(\mathrm{R}_{8}\right)$ labeled with FITC as a reference compound.

The cellular uptake of CPPs varies with respect to the peptide concentration, the cell type, the cell number, the incubation volume and the incubation time. ${ }^{17,19,29}$ Therefore, we carefully performed experiments between $r_{8}$ and $R_{8}$ to ensure that the experimental conditions were comparable. We employed the HeLa human cell line - reportedly a difficult one for cytosolic labeling at low concentrations of CPPs ${ }^{16-19}$ as our cellular model system.

First, we used confocal laser scanning microscopy (CLSM) to analyze the intracellular localization of FITC- $\mathrm{r}_{8}$ and FITC-R 8 . The HeLa cells were monitored without fixing to prevent any artifactual redistribution of CPPs produced by the fixation procedure. ${ }^{16}$ Any cells that were stained with PI were excluded from the analysis. To remove the peptides associated with the outer plasma membrane, we used trypan blue, rather than the moretypical trypsin, ${ }^{16}$ to wash all of the cells prior to analysis; trypsin is not an effective reagent to digest outer-membrane-bound oligoarginines containing D-arginine residues, whereas trypan blue $(500 \mu \mathrm{g} /$ $\mathrm{mL}$ ) can quench more than $80 \%$ of the cell-surface FITC emission and has been used widely in previous studies. $^{30-32}$

Although $\mathrm{R}_{8}$ exhibited the most diffuse pattern with a small amount of vesicle staining at a high concentration $(10 \mu \mathrm{M})$, most of the FITC-R mol- $_{8}$ ecules were trapped in punctate structures, with no significant cytosolic diffusion or nuclear accumulation at concentrations ranging from 2.5 to $5 \mu \mathrm{M}$ (see Fig. 1), in good agreement with the distributions described by others. ${ }^{17}$ Under the same conditions, the intracellular distribution pattern of $\mathrm{r}_{8}$ was significantly different from that of $\mathrm{R}_{8}$. FITC$\mathrm{r}_{8}$ underwent diffuse localization throughout the cytosol, with significant accumulation in the nucleoli at concentrations ranging from 1 to $10 \mu \mathrm{M}$ (see Fig. 1), which is similar to the previous observation of $\mathrm{r}_{10} \cdot{ }^{24}$ The fluorescence signal at concentrations lower than $1 \mu \mathrm{M}$ was too weak to be detected (data not shown). PI did not enter the cells, indicating that the plasma membranes were intact (data not shown). These results showed that the change in chirality of the peptides from L to D affect cellular localization of CPPs.

\subsection{The uptake mechanism of octa-D-arginine $\left(\mathrm{r}_{8}\right)$}

Endocytosis, including macropinocytosis has been pointed out to be the major internalization pathway of L-arginine oligomers at low concentrations. ${ }^{17}$ The internalization mechanism employed by $\mathrm{r}_{8}$ is unclear. It is highly unlikely that the strong diffuse labeling of FITC- $r_{8}$ throughout the cytosol and nucleoli was caused by endocytosis and subsequent release of trapped peptides from the endocytic vesicles, for two reasons: we observed them only after $5 \mathrm{~min}$ of incubation and, few punctate signals were observed during the time course from $5 \mathrm{~s}$ to $5 \mathrm{~min}$ when we monitored the cellular uptake in real time using CLSM (see Fig. 2). To confirm our hypothesis, we 

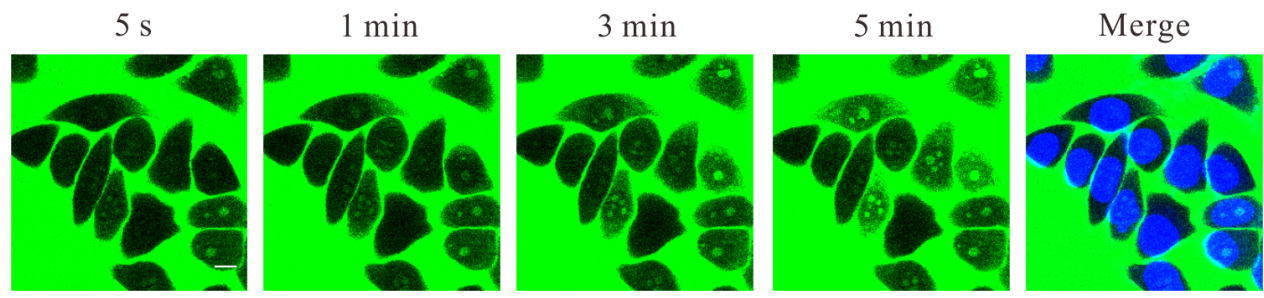

Fig. 2. Confocal microscopy time lapse of the transduction of FITC-r $\mathrm{r}_{8}$ (green, $5 \mu \mathrm{M}$ ) applied to living HeLa cells in serum-free $\operatorname{DMEM}(300 \mu \mathrm{L})$ at $37^{\circ} \mathrm{C}$. The nuclei were stained with Hoechst 33342 (blue). Scale bar: $10 \mu \mathrm{m}$.

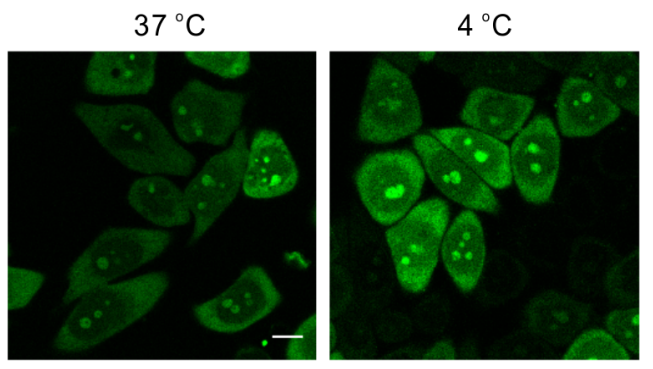

(a)

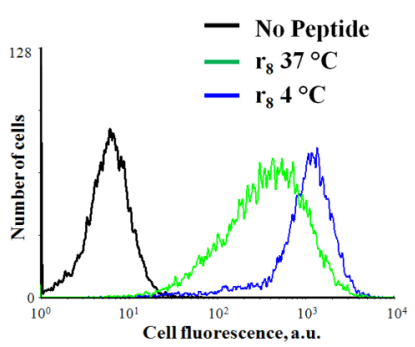

(b)

Fig. 3. Effect of temperature on the cellular uptake of the FITC-labeled peptides. (a) Confocal microscopy images and (b) flow cytometry analyses of living HeLa cells after incubation with the FITC-labeled $\mathrm{r}_{8}(5 \mu \mathrm{M})$ for 5 min in serum-free DMEM $(300 \mu \mathrm{L})$ at $37^{\circ} \mathrm{C}$ or $4^{\circ} \mathrm{C}$. Scale bar: $10 \mu \mathrm{m}$.

co-incubated $\mathrm{r}_{8}$ with LysoTracker Red and the result indicated that $\mathrm{r}_{8}$ did not co-localize with the red LysoTracker at all. Moreover, we decreased the incubation temperature to $4^{\circ} \mathrm{C}$ (i.e., conditions that typically inhibit endocytosis). ${ }^{16,23,33}$ The diffuse distributions of $\mathrm{r}_{8}$ at $5 \mu \mathrm{M}$ were not inhibited by the low temperature, with an even higher fluorescence intensity observed at $4^{\circ} \mathrm{C}$ than at $37^{\circ} \mathrm{C}$ (see Fig. 3). We cannot at present explain why the low temperature enhanced the diffuse distributions, but we note that a similar behavior has been reported previously. ${ }^{23}$ We also used three inhibitors of endocytosis to interfere with individual endocytic pathways. ${ }^{17,34-36} \mathrm{CPZ}$ was used to inhibit clathrin-mediated internalization pathway, EIPA to inhibit macropinocytosis and $\mathrm{M} \beta \mathrm{CD}$ to disrupt the import through caveolae/lipid rafts. The effects of the three inhibitors on the cellular uptake of $r_{8}$ were tested by CLSM and flow cytometry. Figure 4 reveals that preincubation of the cells with all three inhibitors has no detectable effect on the cellular uptake of $r_{8}$.

FITC- $r_{8}$ yielded significant diffuse signals in the cytosol and nucleus within 5 min after the peptide treatment, which was not inhibited by both the pharmacological and physical inhibitors of endocytosis. Therefore, as an alternative, it is more likely that the major internalization pathway of $r_{8}$ is not
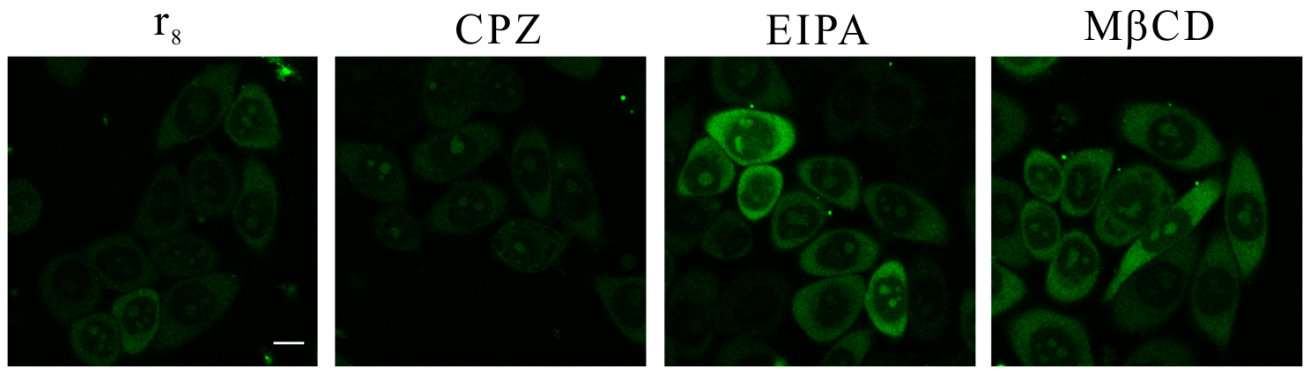

Fig. 4. The uptake of FITC- $\mathrm{r}_{8}$ is independent of endocytosis. HeLa cells were treated with the indicated inhibitor for 30 min at $37^{\circ} \mathrm{C}$ or remained untreated, followed by incubation for a further 5 min with FITC-r $8(5 \mu \mathrm{M})$ in the absence or presence of the respective inhibitor. Scale bar: $10 \mu \mathrm{m}$. 

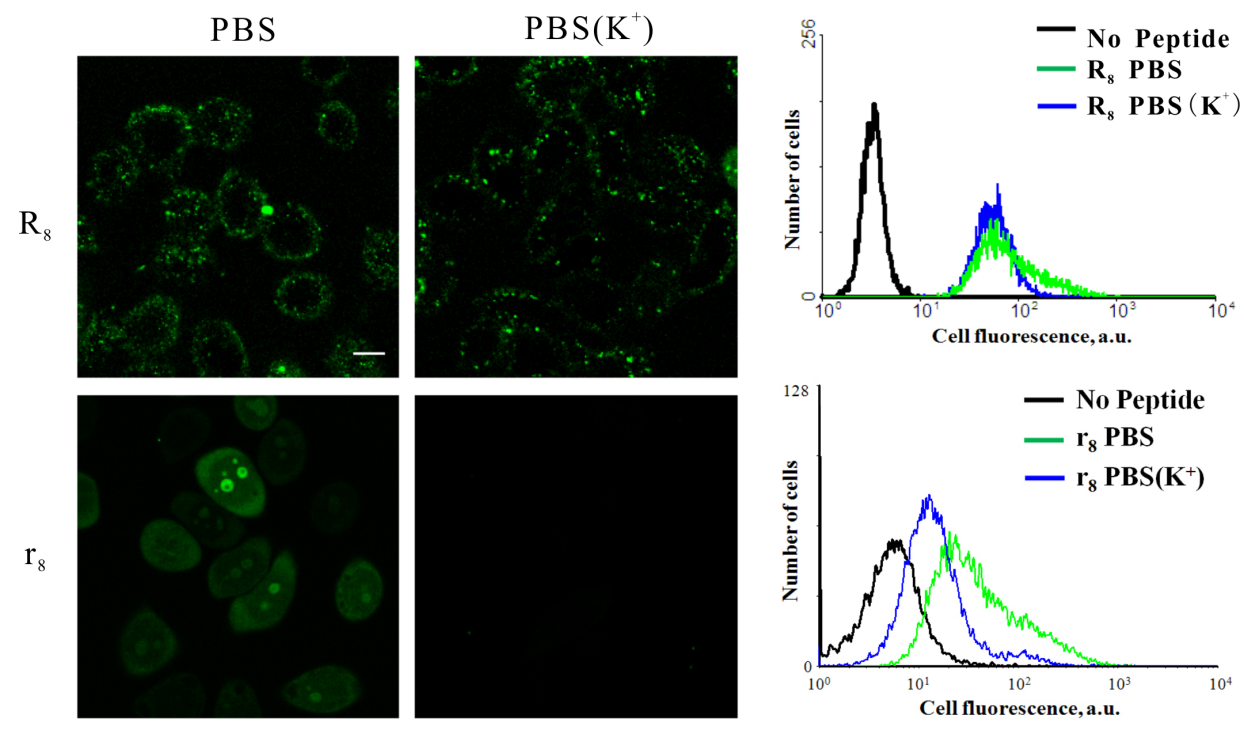

(a)

(b)

Fig. 5. Effect of membrane potential on the cellular uptake of $r_{8}$ and $R_{8}$. (a) Confocal microscopy images and (b) flow cytometry analyses of living HeLa cells after incubation with the FITC-labeled peptides $(2.5 \mu \mathrm{M})$ for 5 min at $37^{\circ} \mathrm{C}$ in $\mathrm{PBS}$ or $\mathrm{PBS}\left(\mathrm{K}^{+}\right)$. Scale bar: $10 \mu \mathrm{m}$.

endocytosis but direct membrane translocation, another possible entry route of CPPs. Direct membrane translocation has been proposed to lead to the diffuse distribution of CPPs in the cytoplasm and nucleus ${ }^{34,37}$ and is driven by the transmembrane potential. ${ }^{38,39}$ Thus, we test whether the membrane potential has effect on the cellular uptake of $\mathrm{r}_{8}$. We incubated HeLa cells with FITC-r $\mathrm{r}_{8}$ at $2.5 \mu \mathrm{M}$ for $5 \mathrm{~min}$ in $\mathrm{PBS}\left(\mathrm{K}^{+}\right)$buffer containing a high concentration of potassium ions to eliminate the membrane potential. ${ }^{38-40}$ We found that the cellular uptake of $\mathrm{r}_{8}$ decreased by more than $80 \%$ when we treated the cells with $\mathrm{PBS}\left(\mathrm{K}^{+}\right)$buffer [see Fig. 5(b)]. In contrast, for $R_{8}$, which is taken up mainly through endocytosis, both the punctate staining and the cellular uptake efficiency were unaffected by the addition of $\mathrm{K}^{+}$(see Fig. 5). Taken together, all the above results showed that the diffuse labeling of FITC- $\mathrm{r}_{8}$ is not due to endocytosis, but rather direct membrane translocation driven by the membrane potential and the backbone stereochemistry that affect the uptake mechanism of oligoarginines.

\section{Discussion}

D-arginine oligomers have been widely used as intracellular delivery vectors in in vivo application due to their high cellular uptake efficiency and great protease resistance. However, their internalization pathway is incompletely understood. The characterization of the mechanism of cellular internalization is essential because the uptake pathways determine the intracellular destinations and biological efficacy of CPPs and their cargos. In this study, we showed that octa-D-arginine exhibits a diffuse intracellular distribution in the cytoplasm, nucleus and nucleoli of living cells, even at low concentrations. The cellular uptake of $r_{8}$ was not inhibited by both the endocytic inhibitors and low temperature. In contrast, eliminating the membrane potential decreased the cellular uptake of $r_{8}$ dramatically. These results suggest that $r_{8}$ was predominantly taken up by the cells via direct membrane translocation, a nonendocytic manner driven by the transmembrane potential. $R_{8}$ and $r_{8}$ entered the cells by two clearly distinct internalization pathways, suggesting that the backbone stereochemistry affects the uptake mechanism of oligoarginines. The results here might provide useful guidelines for the design and applications of CPPs in the delivery of biologically active cargos.

\section{Acknowledgments}

We thank the Analytical and Testing Center, HUST, for the spectral measurements. This work was supported by the National High-Tech Research 
and Development Program of China (863 Program: 2008AA02Z107), the National Natural Science Foundation of China (grant no. 30800183), and the Scientific Research Foundation for the Returned Overseas Chinese Scholars, State Education Ministry (Y.-H. Zhang).

\section{References}

1. F. Heitz, M. C. Morris, G. Divita, "Twenty years of cell-penetrating peptides: From molecular mechanisms to therapeutics," Br. J. Pharmacol. 157, 195206 (2009).

2. P. M. Fischer, "Cellular uptake mechanisms and potential therapeutic utility of peptidic cell delivery vectors: Progress 2001-2006," Med. Res. Rev. 27, 755-795 (2007).

3. S. B. Fonseca, M. P. Pereira, S. O. Kelley, "Recent advances in the use of cell-penetrating peptides for medical and biological applications," Adv. Drug Deliv. Rev. 61, 953-964 (2009).

4. P. A. Wender, D. J. Mitchell, K. Pattabiraman, E. T. Pelkey, L. Steinman, J. B. Rothbard, "The design, synthesis, and evaluation of molecules that enable or enhance cellular uptake: Peptoid molecular transporters," Proc. Natl. Acad. Sci. USA 97, 13003-13008 (2000).

5. D. J. Mitchell, L. Steinman, D. T. Kim, C. G. Fathman, J. B. Rothbard, "Polyarginine enters cells more efficiently than other polycationic homopolymers," J. Pept. Res. 56, 318-325 (2000).

6. P. A. Wender, W. C. Galliher, E. A. Goun, L. R. Jones, T. H. Pillow, "The design of guanidiniumrich transporters and their internalization mechanisms," Adv. Drug Deliv. Rev. 60, 452-472 (2008).

7. I. A. Khalil, K. Kogure, S. Futaki, H. Harashima, "High density of octaarginine stimulates macropinocytosis leading to efficient intracellular trafficking for gene expression," J. Biol. Chem. 281, 3544-3551 (2006).

8. A. Mann, G. Thakur, V. Shukla, M. Ganguli, "Peptides in DNA delivery: Current insights and future directions," Drug Discov. Today 13, 152-160 (2008).

9. B. U. Samuel, B. Hearn, D. Mack, P. Wender, J. Rothbard, M. J. Kirisits, E. Mui, S. Wernimont, C. W. Roberts, S. P. Muench, D. W. Rice, S. T. Prigge, A. B. Law, R. McLeod, "Delivery of antimicrobials into parasites," Proc. Natl. Acad. Sci. USA 100, 14281-14286 (2003).

10. T. A. Aguilera, E. S. Olson, M. M. Timmers, T. Jiang, R. Y. Tsien, "Systemic in vivo distribution of activatable cell penetrating peptides is superior to that of cell penetrating peptides," Integr. Biol. 1, 371-381 (2009).

11. P. A. Wender, E. A. Goun, L. R. Jones, T. H. Pillow, J. B. Rothbard, R. Shinde, C. H. Contag, "Real-time analysis of uptake and bioactivatable cleavage of luciferin-transporter conjugates in transgenic reporter mice," Proc. Natl. Acad. Sci. USA 104, 1034010345 (2007).

12. K. Takayama, Y. Suehisa, T. Fujita, J. Nguyen, S. Futaki, A. Yamamoto, Y. Kiso, Y. Hayashi, "Oligoarginine-based prodrugs with self-cleavable spacers for Caco-2 cell permeation," Chem. Pharm. Bull. 56, 1515-1520 (2008).

13. J. B. Delehanty, I. L. Medintz, T. Pons, F. M. Brunel, P. E. Dawson, H. Mattoussi, "Self-assembled quantum dot-peptide bioconjugates for selective intracellular delivery," Bioconjug. Chem. 17, 920-927 (2006).

14. H. Räägel, P. Säälik, M. Hansen, Ü. Langel, M. Pooga, "CPP-protein constructs induce a population of nonacidic vesicles during trafficking through endo-lysosomal pathway," J. Control. Release 139, 108-117 (2009).

15. E. A. Goun, R. Shinde, K. W. Dehnert, A. AdamsBond, P. A. Wender, C. H. Contag, B. L. Franc, "Intracellular cargo delivery by an octaarginine transporter adapted to target prostate cancer cells through cell surface protease activation," Bioconjug. Chem. 17, 787-796 (2006).

16. J. P. Richard, K. Melikov, E. Vives, C. Ramos, B. Verbeure, M. J. Gait, L. V. Chernomordik, B. Lebleu, "Cell-penetrating peptides a reevaluation of the mechanism of cellular uptake," J. Biol. Chem. 278, 585-590 (2003).

17. F. Duchardt, M. Fotin-Mleczek, H. Schwarz, R. Fischer, R. Brock, "A comprehensive model for the cellular uptake of cationic cell-penetrating peptides," Traffic 8, 848-866 (2007).

18. I. Nakase, M. Niwa, T. Takeuchi, K. Sonomura, N. Kawabata, Y. Koike, M. Takehashi, S. Tanaka, K. Ueda, J. C. Simpson, A. T. Jones, Y. Sugiura, S. Futaki, "Cellular uptake of Arginine-rich peptides: Roles for macropinocytosis and actin rearrangement," Mol. Ther. 10, 1011-1022 (2004).

19. R. Fischer, M. Fotin-Mleczek, H. Hufnagel, R. Brock, "Break on through to the other side-biophysics and cell biology shed light on cell-penetrating peptides," ChemBioChem 6, 2126-2142 (2005).

20. E. A. Goun, T. H. Pillow, L. R. Jones, J. B. Rothbard, P. A. Wender, "Molecular transporters: Synthesis of oligoguanidinium transporters and their application to drug delivery and real-time imaging," ChemBioChem 7, 1497-1515 (2006). 
21. C. Foerg, H. P. Merkle, "On the biomedical promise of cell penetrating peptides: Limits versus prospects," J. Pharm. Sci. 97, 144-162 (2008).

22. A. El-Sayed, S. Futaki, H. Harashima, "Delivery of macromolecules using arginine-rich cell-penetrating peptides: Ways to overcome endosomal entrapment," AAPS J. 11, 13-22 (2009).

23. M. M. Fretz, N. A. Penning, S. Al-Taei, S. Futaki, T. Takeuchi, I. Nakase, G. Storm, A. T. Jones, "Temperature-, concentration-and cholesteroldependent translocation of L-and D-octa-arginine across the plasma and nuclear membrane of CD34 ${ }^{+}$ leukaemia cells," Biochem. J. 403, 335-342 (2007).

24. R. M. Martin, G. Tünnemann, H. Leonhardt, M. C. Cardoso, "Nucleolar marker for living cells," Histochem. Cell Biol. 127, 243-251 (2007).

25. T. D. Mckee, J. Chen, I. Corbin, G. Zheng, R. Khokha, "Quantifying nanoparticle transport in vivo using hyperspectral imaging with a dorsal skinfold window chamber," J. Innov. Opt. Health. Sci. 5, 1250023 (2012).

26. J. Guo, Z. Fan, Z. Gu, X. Wei, "Studying the role of macrophages in circulating prostate cancer cells by in vivo flow cytometry," J. Innov. Opt. Health. Sci. 5, 1250027 (2012).

27. J. Qu, L. Liu, Y. Shao, H. Niu, B. Z. Gao, "Recent progress in multifocal multiphoton microscopy," J. Innov. Opt. Health. Sci. 5, 1250018 (2012).

28. M. Ranji, S. Nioka, H. N. Xu, B. Wu, L. Z. Li, D. L. Jaggard, B. Chance, "Fluorescent images of mitochondrial redox states in in situ mouse hypoxic ischemic intestines," J. Innov. Opt. Health Sci. 2, 365-374 (2009).

29. M. Hällbrink, J. Oehlke, G. Papsdorf, M. Bienert, "Uptake of cell-penetrating peptides is dependent on peptide-to-cell ratio rather than on peptide concentration," Biochim. Biophys. Acta 1667, 222-228 (2004).

30. A. Manceur, A. Wu, J. Audet, "Flow cytometric screening of cell-penetrating peptides for their uptake into embryonic and adult stem cells," Anal. Biochem. 364, 51-59 (2007).

31. I. Massodi, G. L. Bidwell III, D. Raucher, "Evaluation of cell penetrating peptides fused to elastin-like polypeptide for drug delivery," J. Control. Release 108, 396-408 (2005).

32. T. Holm, H. Johansson, P. Lundberg, M. Pooga, M. Lindgren, Ü. Langel, "Studying the uptake of cell-penetrating peptides," Nat. Protoc. 1, 10011005 (2006).

33. J. R. Maiolo, M. Ferrer, E. A. Ottinger, "Effects of cargo molecules on the cellular uptake of argininerich cell-penetrating peptides," Biochim. Biophys. Acta Biomembr. 1712, 161-172 (2005).

34. A. Subtil, A. Hemar, A. Dautry-Varsat, "Rapid endocytosis of interleukin 2 receptors when clathrincoated pit endocytosis is inhibited," J. Cell Sci. 107, 3461-3468 (1994).

35. M. A. West, M. S. Bretscher, C. Watts, "Distinct endocytotic pathways in epidermal growth factorstimulated human carcinoma A431 cells," J. Cell Biol. 109, 2731-2739 (1989).

36. P. Keller, K. Simons, "Cholesterol is required for surface transport of influenza virus hemagglutinin," J. Cell Biol. 140, 1357-1367 (1998).

37. T. B. Potocky, A. K. Menon, S. H. Gellman, "Cytoplasmic and nuclear delivery of a TAT-derived peptide and a $\beta$-peptide after endocytic uptake into HeLa cells," J. Biol. Chem. 278, 50188-50194 (2003).

38. J. B. Rothbard, T. C. Jessop, P. A. Wender, "Adaptive translocation: The role of hydrogen bonding and membrane potential in the uptake of guanidinium-rich transporters into cells," Adv. Drug Deliv. Rev. 57, 495-504 (2005).

39. J. B. Rothbard, T. C. Jessop, R. S. Lewis, B. A. Murray, P. A. Wender, "Role of membrane potential and hydrogen bonding in the mechanism of translocation of guanidinium-rich peptides into cells," J. Am. Chem. Soc. 126, 9506-9507 (2004).

40. M. Kosuge, T. Takeuchi, I. Nakase, A. T. Jones, S. Futaki, "Cellular internalization and distribution of arginine-rich peptides as a function of extracellular peptide concentration, serum, and plasma membrane associated proteoglycans, Bioconjug. Chem. 19, 656-664 (2008). 